Maxillo Facial Surgery Unit, Catholic University Medical School, Rome, Italy* Ospedale „S. Giovanni Battista”, Foligno (PG), Italy**

Department of Biomedical Surgical and Dental Sciences, Maxillo-Facial and Odontostomatology Unit, Fondazione Cà Granda IRCCS Ospedale Maggiore Policlinico, University of Milan. Milan, Italy*** Semmelweis Egyetem Arc-, Állcsont-, Szájsebészeti és Fogászati Klinika***

\title{
Gorham-Stout betegség a felső állcsonton: esetleírás és irodalmi áttekintés
}

ALESSANDRO MORO*, UMBERTO GARAGIOLA***, GIANMARCO SAPONARO*, GIULIO GASPARINI*, ROBERTO BONIELLO*, MARCO FALCHI ${ }^{\star *}$, GIOVANNI BARBINI ${ }^{\star *}$, ENRICO CRISTALLINI ${ }^{\star *}$, GIUSEPPE D'AMATO*, GALAMBOS BENCE ${ }^{\star * \star *}$, SANDRO PELO*

\begin{abstract}
A Gorham betegség, vagy „vanishing bone disease” ismeretlen etiológiájú, ritka kórkép, melyet csontfelszívódás jellemez. Előfordulhat a csontváz bármely részén, azonban leggyakrabban a medencecsont, a humerus, a törzs csontozata és a mandibula érintett. A csontreszorpció mechanizmusa tisztázatlan, de az oszteolítikus területeken a nyirokerek lokalizált endothel proliferációja mutatható ki. A diagnózis felálítása egyéb fertőzés, gyulladásos folyamat, neoplázia és endokrinológiai okok kizárását követően a klinikai, radiológiai és szövettani kép alapján történik. A Gorham betegség kezelésekor szóba jöhetnek gyógyszerek; osteoclast ellenes szerek (biszfoszfonátok) és alfa-2b interferon. Sugárkezelés, amely a csontszöveten belüli érburjánzás szklerózisát idézi elő. Sebészi terápia, mely az érintett terület rezekciójából és annak csonttal és/vagy protézissel való rekonstrukciójából áll. Cikkünk egy Gorham betegségben szenvedő 67 éves nőbeteg esetét mutatja be, akinek a maxillája jobb oldala, a processus alveolarisa, a zygomája, és az orbitaalapja volt érintett. A betegség kezdetén a jobb oldali felső nagyörlők meglazulásában nyilvánult meg, ezzel parodontitis klinikai képét utánozva, melyet a már meglévő, tisztázatlan eredetű kettős látás súlyosbodása követett. A beteg zoledronsav, D-vitamin, és kalcium-karbonát kezelésben részesült 12 hónapon át, mely a betegség progressziójának fékentartásában hatásosnak bizonyult.
\end{abstract}

Kulcsszó: Csontfelszívódás, Gorham betegség, zoledronsav kezelés

\section{Bevezetés}

A Gorham-Stout betegség (GSD) egy ritka elváltozás, melyet egy, vagy több csontot érintő elörehaladó oszteolízis jellemez és spontán fracturához vezethet.

Multicentrikus formáit ritkán írják le [1] és nincs különbség a nemek közti előfordulásában, öröklődést nem mutat [2]. Bármely korban előfordulhat és jellemzően a felszívódott csont helyét abnormálisan burjánzó nyirokerek töltik ki [3]. Különböző definíciók születtek a betegség leírására, például „phantom bone desease”, massive osteolysis, disappearing, vagy vanishing bone disease, acute spontaneous absorption of bone, hemangiomatosis és lymphangiomatosis [4].

A Gorham betegséget Hardegger és msti. klasszifikálták négy más típusú oszteolízissel együtt Torg és msti. leírása alapján [5].

A GSD hátterében nem endokrin és nem metabolikus elváltozások állnak, és akárcsak a csontfelszívódás mechanizmusa, a betegség aetilológiai faktorai is ismeretlenek [6].

Megnövekedett oszteoklaszt aktivitást írtak le vér- és nyirokérburjánzással, mint a progresszív csontfelszívó- dás lehetséges patológiai mechanizmusát [4, 7, 8, 9, 10, $11,12]$.

A betegség érintheti a perioszteumot, bizonyos esetekben még a környező lágyszöveteket is.

Sebészi beavatkozás, kemoterápia és irradiáció merülhet fel mint lehetséges kezelés, gyakran azonos eredménnyel, tehát a GSD kezelése egyelőre vitatott.

Prognózisa változatos és kiszámíthatatlan, mely az apróbb eltéréstől a halálig terjedő skálán mozog.

\section{Esetleírás}

Szemészeti osztályról egy már meglévő kettőslátás roszszabbodására panaszkodó 67 éves nőbeteget irányítottak az arc-, állcsontszebészeti osztályunkra, akinek panaszai összefüggésben álltak növekvő arc aszimmetriájával, járomív atrófiájával és lokalizált fájdalmával.

A beteg elmondása szerint több mint hat hónapja észlelte a felső állcsonton fogainak fokozódó mozgathatóságát.

Előzőleg más osztályon parodontitiszt diagnosztizáltak, és azt a szakma szabályainak megfelelően kezel- 
ték. A beteg felső második nagyőrlőjét is eltávolították, a kezelések ellenére azonban a fogak mobilitása tovább nőtt.

A pácienst a szemészek már megfigyelés alatt tartották az ismeretlen eredetű diplópiája miatt, mely hirtelen rosszabbodni kezdett, és ezzel egyidejüleg az arc aszimmetrikussá vált, melynek hátterében a járomív és a maxilla ellaposodása állt. Mindezek miatt utalták a beteget az arc-, állcsontsebészeti osztályra további vizsgálatok céljából.

A klinikai vizsgálatok jobb oldali zygoma és orbita asszimmetriát, horizontális és vertikális kettőslátást mutattak. (1. kép)

A betegről Hess teszt, panorámaröntgen (2. kép), fejnyak CT, illetve teljes test CT készült. A Hess screen teszt felfelé tekintéskor kettőslátást, továbbá a musculus rectus superior gyengeségét mutatta ki.

A panorámaröntgen felvétel a jobb felső fogmedernyúlvány sorvadására derített fényt, a CT pedig megerősítette, hogy a maxilla jobb oldalán oszteolítikus lézió van jelen, mely összefüggésbe hozható a jobb orbita laterális falának átalakulásával.

Az MRI vizsgálat oszteolítikus, errozív elváltozást mutatott ki a jobb maxillán, mely érinti az arcüreget, a járomívet és a szemüreg alapját; az arcüreg térfogata lecsökkent, összeesett és deformálódott.

A teljes test CT felvételen neoplasztikus lézió nem volt megfigyelhető.

Az intraorális klinikai vizsgálat gingivitisz hiányát, elégséges szájhigiénét, 15, 16-os fogak grade II mobilitását mutatta. A parodontológiai vizsgálat tapadásveszteséget és parodontológiai tasakokat mutatott ki.

Az elváltozásból történő mintavételt és laboratóriumi vizsgálatot kértünk, időközben a 16, 15, és 14-es fogakat súlyos mozgathatóságuk miatt el kellett távolítani.

Az alveoláris csontot kitöltő fibrózus szövetrészlet hisztológiai vizsgálata (3. kép) kötőszövetet, érproliferációt, limfocitákat, plazmasejteket és oszteocitákkal körülvett csont trabekulákat írt le.

A laboreredmények normálisnak bizonyultak.

Hagyományos röntgenfelvételek készültek a mellkasról, végtagokról és a gerincről, ezeken kóros eltérés nem volt kimutatható.

Jelen eset a Gorham betegséggel kapcsolatban a Hoffman és msti. által 1983-ban leírt diagnosztikai kritériumoknak [7] felel meg:

- örökletes, metabolikus, neoplasztikus, immunológiai és fertőzéses okok kizárásra kerültek,

- non-expanzív, non-ulceratív elváltozás, klinikailag lokálisan előrehaladó csontfeszívódás látható,

- belszervi érintettség nincs,

- szövettani vizsgálat celluláris atypiával nem járó angiomatózus szövetet írt le minimális oszteoblasztos válasszal, disztrófiás kalcifikáció nélkül (3. kép).

Az irodalomban [7, 8] sebészi eltávolítást követően a betegség kiújulásról számoltak be, ezért az elsődleges sebészi terápiát elvetettük.
Habár a sugárterápiát a Gorham betegség hatékony kezelésének tartják, a gyógyszeres terápia mellett döntöttünk, figyelembe véve az irradiációnak az orbita területén lehetséges veszélyes mellékhatásait.

A beteg ezt követően i.v. zoledronsav kezelést kapott (4 mg 28 naponta) hat hónapon keresztül. A kreatinin- és kalciumszintet havi rendszerességgel monitorozták.

A betegség nyomon követése céljából panorámaröntgen, CT és MRI készült felváltva, kéthavonta, egy éven keresztül.

\section{Eredmények}

Hat hónap kezelés után a betegség progressziója megállt, további csontfelszívódást nem észleltünk (4. kép).

A klinikai megítélés pozitívnak bizonyult, miután a fájdalom elmúlt és a fogak fixálódtak.

A radiológiai leletek megerősítették, hogy az oszteolítikus jelenség leállt, és a helyén kezdődő reparatív folyamat zajlik.

A hathónapos követéses CT vizsgálat a lítikus folyamatban korábban érintett processus alveolaris, illetve a palatum területén szklerotikus gyógyulást mutatott ki. Mivel a betegen nem látszottak a gyógyszer okozta ártalmas mellékhatások, további hat hónapig folytattuk a kezelést. Egy év elteltével a betegség progressziójának semmilyen jele nem mutatkozott, így a kezelést felfüggesztettük.

Ha a betegség nyugvó állapota az obszervációs időszak után is igazolható, rekonstrukciós mútét tervezhető, mely az orbitaalap helyreállítását, a jobb zygoma és fogmedernyúlvány autológ csonttal való augmentációját, illetve az orca zsírfeltőltését foglalja magába.

\section{Megbeszélés}

Az első, „vanishing bone disease”-t leíró eset 1838-ban Jackson nevéhez füződik [13]. Romer írt először egy, a fiatal gyermekek állcsontjait érintő hasonló kórképről 1924-ben. Gorham 1945-ben, illetve Gorham és Stout 1955-ben mutattak be egy esetsorozatot, mely az állapotot specifikus patológiai folyamatként definiálja [14, 15].

Hozzávetőlegesen 150 esetleírás lelhető fel a szakirodalomban, a betegség ritkának mondható, a beszámolók túlnyomó része az állcsontokban írja le a kórfolyamatot. Habár a maxillában és a mandibulában jelenik meg leggyakrabban, bármely csont érintett lehet.

Tizennégy esetben a fej több, egymással érintkező csontja volt beteg, ezzel feltételezhetően a kórkép egy előrehaladottabb állapotáról volt szó [16-19].

Míg a mandibula egyedül is érintett lehet, addig a maxillában általában más csontokkal együtt jelenik meg. A publikált esetekben a diagnózis felállításakor betöltött átlag életkor 33,7 év, melynek szórása születéstől 72 éves korig terjed. Ahol a GSD több mint egy csontot érintett, a prognózis a lokációtól függően változhat. 


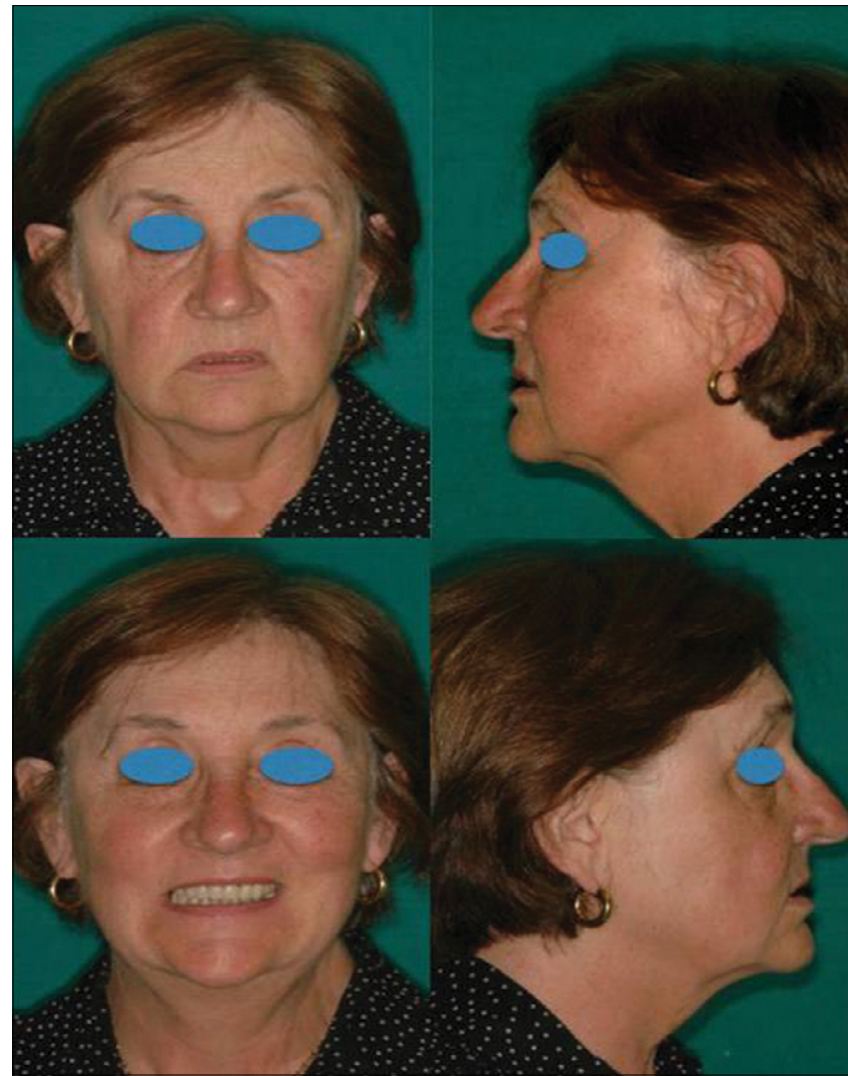

1. kép: Páciens kezelés előtt

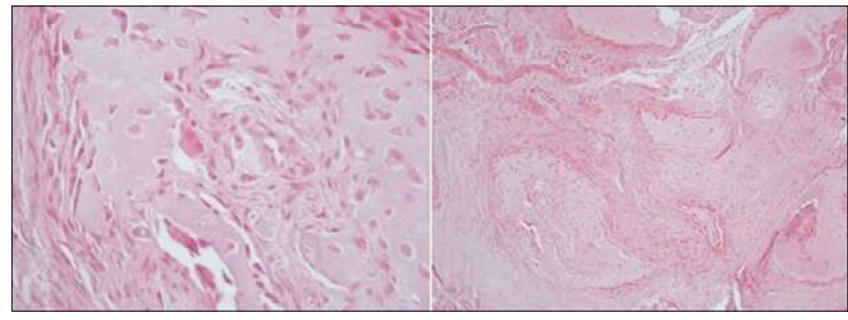

3. kép: Szövettani metszet,

melyen kötőszövet, érproliferáció, limfociták, plazmasejtek és oszteoklasztokkal körülvett csonttrabekulák láthatók.

Több teória is született a betegség hátterében húzódó patológiai folyamatok leírására, a GSD etiológiája és kórélettana továbbra is bizonytalan. Bár a traumának komoly szerepet tulajdonítanak a betegség kialakulásában, az esetek felében mindennemű traumás ok kizárható. Neurovaszkuláris változások, érszövetek csontban történő primer elváltozása, vér- és nyirokerek endothel diszpláziája lehetnek a patogenezis esetleges okai. Úgy tûnik, hogy a GSD oszteolítikus jelensége inkább érproliferációval, gyulladással, $\mathrm{PH}$ és egyéb helyi környezeti viszonyok változásával hozható összefüggésbe, mintsem valamilyen megváltozott oszteoklaszt aktivitással. Immunohisztokémiai vizsgálatok arra engednek következtetni, hogy a beteg lágyszöveteket, a csont kortikális és velőállományát nyirokerek szövik át, melyek alapvetően nem elemei a csontszö-

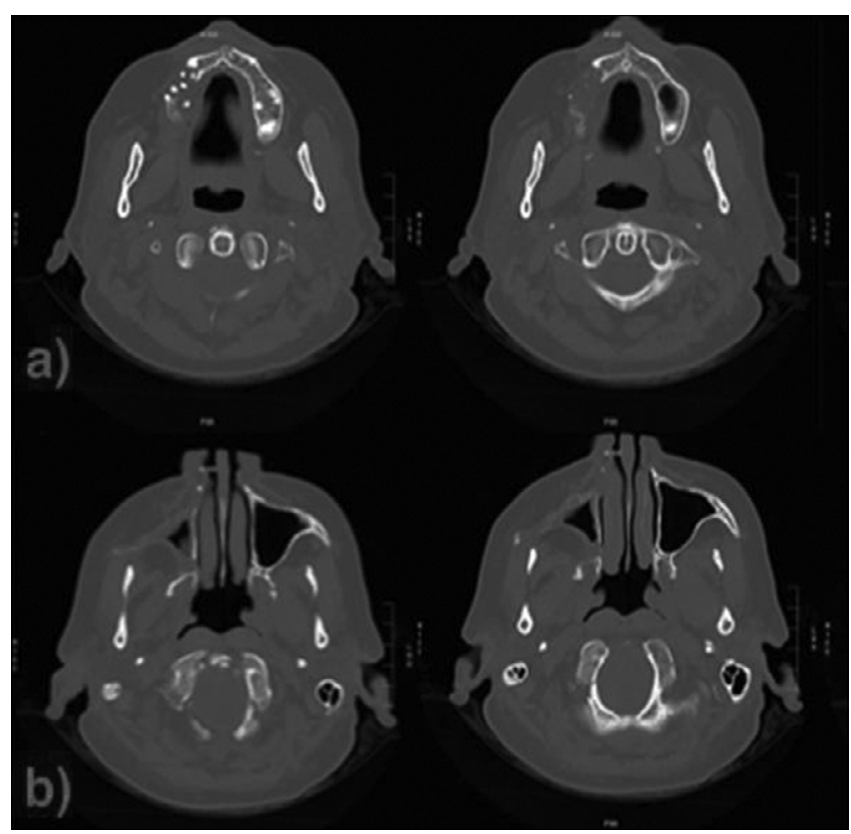

2. kép: Kezelés előtti CT felvétel, melyen a jobb maxilla oszteolítikus léziójával összefüggésben lévő

összeesett jobb oldali arcüreg, és a jobb orbita laterális fala keményszöveteinek lágyrészes helyettesítés látható.

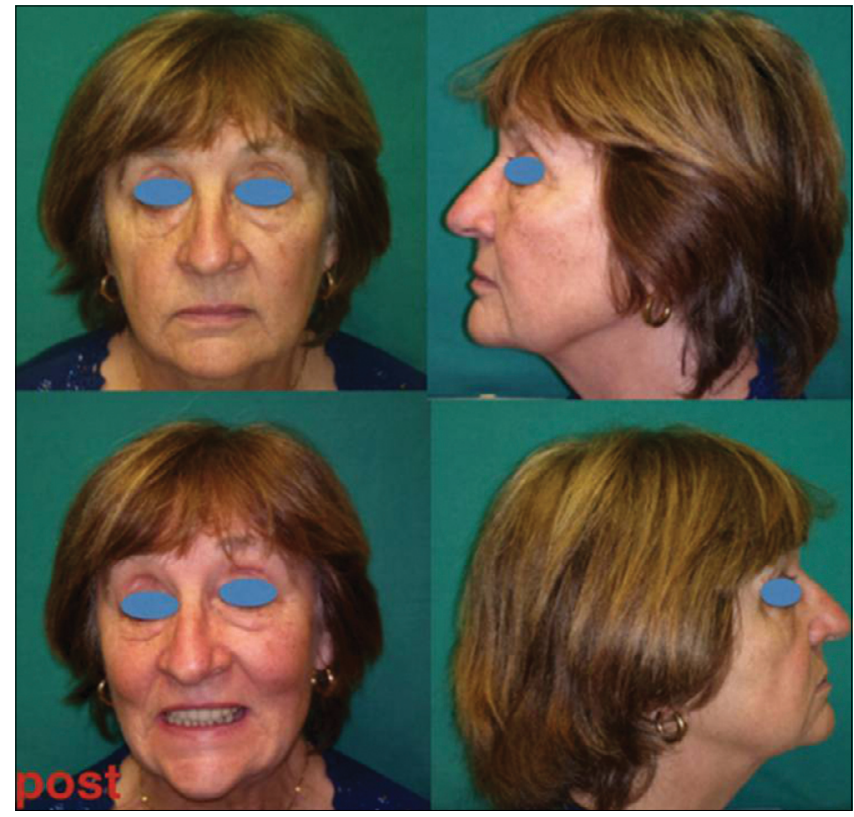

4. kép: Páciens kezelés után

vetnek. A megváltozott nyirokerek nem mutatnak neoplasztikus elváltozást. Mindezek alapján feltételezhető, hogy GSD-ben a csontfelszívódásért inkább a limfatikus erek nem tumoros elváltozása, mintsem a vérerek felelősek [20, 21, 22, 23, 24, 25]. A csontfelszívódás létrejöhet a folyadékkal teli nyirokérburjánzás, vagy az osteoklasztok és osteoblasztok megváltozott aktivitása következményeként.

A diagnózis klinikai, radiológiai és szövettani vizsgá- 
latokon alapszik; egyéb fertőzést, gyulladásos folyamatot, neoplasztikus és endokrinológiai betegségeket ki kell zárni. A haematológiai vizsgálatok eredményei általában normálisak, a betegség nincs összefüggésben hormonális vagy metabolikus változásokkal.

A röntgen a diagnosztikai folyamat alapját képzi, mivel kimutatja a részleges, vagy teljes csonthiányt, amely a csontreszorpciós jelenség kiterjedésével marginális szklerotikus reakció nélküli, összefüggő területet képez. A korai radiológiai leletek megegyeznek az oszteoporózisban is tapasztalható denzitás-csökkenéssel. Az egymással érintkező csontok akár teljes vagy részleges eltúnését okozó prorgresszív csontfelszívódás, a megmaradt csontok elvékonyodása vagy patológiás törések a betegség elörehaladott stádiumának jellemzői [26, 27, 28, 29].

A CT a diagnózis felállításában és a betegség kiterjedésének megítélésében fontos. Az MRI jól demonstrálja a csontok denzitásbeli különbségeit. A szövettani vizsgálat elengedhetetlen a diagnózis kimondásához. A betegség hisztológiai jellemzői oly módon írhatók le, mint korai fázis, melyben a reabszorbeálódó csontszövet helyét vaszkularizált szövet tölti ki, később a kötőszövet felszaporodása a jellemző.

A tünetek nagyban függenek a betegség megjelenésének helyétől, a betegek általánosságban lokalizált fájdalomról és deformitással járó funkciós problémákról számolnak be. A maxillofaciális régió esetében a betegek egyharmadánál jelentkezett malokklúzió, deformitás és fájdalom. A fogak mozgathatóvá válása és az ínyvérzés alveoláris érintettségre utal, míg a betegség más lokalizációja különböző tünetegyütteseket produkálhat, ugyanakkor a betegség csendes kialakulása sem ritka.

A Gorham-Stout szindróma diagnózisának felállítására Heffez és mtsi. [7] az alábbi 8 kritériumot ajánlották:

- a biopszia angiomatózus szövetet mutat,

- szöveti atípia hiánya,

- minimális oszteoblasztos válasz és disztrófiás kalcifikáció hiánya,

- lokális, progresszív csontfelszívódás kimutatása,

- non-expanzív, non-ulceratív elváltozás,

- belszervi érintettség hiánya,

- oszteolítikus radiológiai jelek,

- negatív öröklődési, metabolikus, neoplasztikus, immunológiai, vagy infektológiai kóroktan

A szövődmények akár végzetes kimenetelúek is lehetnek és halál, vagy súlyos elváltozások léphetnek föl, ha a nyaki csigolyák, a mellkas, medence, vagy a koponya érintettek. Chylothorax körülbelül a páciensek $25 \%$-ánál jelentkezhet, mely végül légzési elégtelenséghez vezet. A bordaérintettség neurológiai szövődményeket, paralízist, halált okozhat. Annak ellenére, hogy jóindulatú elváltozásként tartják számon, a GSD prognózisa kiszámíthatatlan és nincs rutin terápiája. A kezelése jelenleg is kutatás tárgya, habár számos kü- lönböző terápiás lehetőségekről számoltak be változó eredményekkel [30, 31].

A lehetséges terápiás módszerek az alábbiak:

- Gyógyszeres kezelés: különféle gyógyszerekkel próbálkoztak: oszteoklaszt gátló szerek, mint a biszfoszfonátok (i.v. zoledronsav, $4 \mathrm{mg}, 28$ naponta), interferonok (50 $\mu \mathrm{g}$ hetente), D-vitamin és orális kalcium-karbonát. A zoledronsav és interferon közti szinergista mechanizmus erős antiangiogenetikus hatású, mely jelenleg a legjobb terápiás eredményeket mutatja.

- Radioterápia: a proliferálódó vérerek szklerózisának gyorsítása révén hat, köszönhetően az endothel sejtek sugárérzékenységének, így megelőzve az erek burjánzását; 30-45 Gy, 2 Gy-es részletekben úgy tünik, jó klinikai eredményeket hoz, néhány késői szövődmény mellett.

- Sebészi terápia: a GSD komplikációinak a kezelésében fontos lehet, mint a chylothorax, vagy a gerinccsigolyák stabilitás vesztése miatt. Több szerző szerint az érintett szegment rezekciója és az ezt követő rekonstrukció csontgrafttal és/vagy protézissel a választandó terápia. Gondolni kell azonban arra, hogy az elváltozás recidiválhat, annak oszteolítikus természete és a csontgraft vagy protézis meglazulása miatt. Ahol nem volt törés vagy masszív csontfelszívódás, csontgraft beültetése mellett javasolt a szelektív embolizáció is (lehetőleg pre-op) [32, 33, 34, 35, 36].

\section{Konklúzió}

A Gorham betegség egy ritka és nem közismert kórkép, melyet a csontszövet lassú és progresszív felszívódása jellemez. A javasolt terápiás módszerek magukba foglalják a sebészi beavatkozást, a sugárterápiát és gyógyszeres kezelést, de jelenleg nincs rutin terápiás protokoll. Kalcitonin, D-vitamin, alpha $2 \mathrm{~b}$ interferon, oszteoklasztgátló gyógyszerek (biszfoszfonátok) hatékony terápiának túnnek és a relatív kevés káros mellékhatásuk miatt első vonalban javasolják őket. A betegség fej-nyaki lokalizációja esetében gyakran van malokklúzió, alveoláris csontveszteség, fogmobilitás, ínyvérzés és arc aszimmetria. Alveoláris csontveszteség és fogmobilitás észlelhető mint a betegség korai jelei, az állcsontokat érintő GSD-s esetek túlnyomó részében [37].

Miután az érintett terület rezekciójából és rekonstrukciójából álló sebészi terápiát követően előfordul recidíva, javasolt a sebészi rekonstrukciót a betegség gyógyszeres kezelése és a klinikai és radiológiai stabilizáció után végezni.

\section{Rövidítések jegyzéke:}

GSD: Gorham-Stout Disease

CT: Computed tomography

MRI: Magnetic resonance imaging 


\section{Irodalom}

1. Vélez A, Herrera M, Del Rio E, Ruiz-Maldonado R: Gorham's syndrome. Int J Dermatol. 1993; 32 (12): 884-887.

2. Patel DV: Gorham's disease or massive osteolysis. Clin Med Res. 2005; 3 (2): 65-74.

3. Papadakis SA, Khaldi L, Babourda EC, Papadakis S, Mitsitsikas T, SAPKAS G: Vanishing bone disease: review and case reports. Orthopedics. 2008; 31 (3): 278.

4. Gondivkar SM, Gadbail AR: Gorham-Stout syndrome: a rare clinical entity and review of literature. Oral Surg Oral Med Oral Pathol Oral Radiol Endod. 2010; 109 (2): e41-8.

5. Hardegger F, Simpson LA, Segmueller G: The syndrome of idiopathic osteolysis. Classification, review, and case report. J Bone Joint Surg Br. 1985; 67 (1): 88-93.

6. Spadari F, Garagiola U, Dzsida E, Azzı L, Kálmán FS: Burning oral sensation: when is really BMS?]. Fogorv Szle. 2015; 108 (4): 137-143.

7. Heffez L, Doku HC, Carter BL, Feeney JE: Perspectives on massive osteolysis. Report of a case and review of the literature. Oral Surg Oral Med Oral Pathol. 1983; 55 (4): 331-343.

8. Nikolaou VS, Chytas D, Korres D, Efstathopoulos N: Vanishing bone disease (Gorham-Stout syndrome): A review of a rare entity. World J Orthop. 2014; 185 (5): 694-698.

9. Bouloux GF, Walker M, McKelLaR G: Massive osteolysis of the mandible: report of a case with multifocal bone loss. Oral Surg Oral Med Oral Pathol Oral Radiol Endod. 1999; 87 (3): 357-361.

10. BanerJI S, Ni J, Wang SX, CLasper $S$, Su J, et al.: LYVE-1, a new homologue of the CD44 glycoprotein, is a lymph-specific receptor for hyaluronan. J Cell Biol. 1999; 144 (4): 789-801.

11. KaHn HJ, Balley D, Marks A: Monoclonal antibody D2-40, a new marker of lymphatic endothelium, reacts with Kaposi's sarcoma and a subset of angiosarcomas. Mod Pathol. 2002; 15 (4): 434-40.

12. Edwards JR, Williams K, Kindblom LG, Meis-Kindblom JM, HoGENDOORN PC, et al.: Lymphatics and bone. Hum Pathol. 2008; 39 (1): 49-55

13. JACKSON JR: Fibrous Tumour, of 35 Years' Standing, Occupying the Whole of the Buccal Cavity; Removal; Fatal Result. Ind Med Gaz. 1870; 5 (11): 227-229.

14. Gorham LW, Stout AP: Hemangiomatosis and its relation to massive osteolysis. Trans Assoc Am Physicians. 1954; 67: 302-307.

15. Gorham LW, Stout AP: Massive osteolysis (acute spontaneous absorption of bone, phantom bone, disappearing bone); its relation to hemangiomatosis. J Bone Joint Surg Am. 1955; 37-A (5): 985-1004.

16. Bruder E, Perez-Atayde AR, Jundt G, Alomari Al, Rischewski J, et al.: Vascular lesions of bone in children, adolescents, and young adults. A clinicopathologic reappraisal and application of the ISSVA classification. Virchows Arch. 2009; 454 (2): 161-79.

17. Dellinger MT, Garg N, Olsen BR: Viewpoints on vessels and vanishing bones in Gorham-Stout disease. Bone. 2014; 63: 47-52.

18. Dickson GR, Hamilton A, Hayes D, et al.: An investigation of vanishing bone disease. Bone. 1990; 11 (3): 205-10.

19. Assoun J, Richardi G, et al:: CT and MRI of massive osteolysis of Gorham. J Comput Assist Tomogr. 1994; 18 (6): 981-84.

20. Skidmore TB, Lee CM, Авbott TM, Wiggins RH 3Rd, et al.: Gorham disease of the mandible: Radiographic findings and radiotherapy response. Ear Nose Throat J. 2008; 87 (6): E4-7.

21. Moro A, Gasparini G, Foresta E, Saponaro G, Falchi M, Cardarelli L, De Angelis P, Forcione M, Garagiola U, D'Amato G, PeLo S: Alveolar Ridge Split Technique Using Piezosurgery with Specially Designed Tips. Biomed Res Int. 2017; 2017: 4530378.
22. Nir V, Guralnik L, Livnat G, Bar-Yoseph R, Hakim F, Ilivitzki A, Bentur L: Propranolol as a treatment option in Gorham-Stout syndrome: a case report. Pediatr Pulmonol. 2014; 49 (4): 417-419.

23. Kareem BA, Das PK, SAad R: Disappearing bone disease: a case report. Singapore Med J. 1994; 35 (5): 527-528.

24. Dunbar SF, Rosenberg A, Mankin H, Rosenthal D, Suit HD: Gorham's massive osteolysis: the role of radiation therapy and a review of the literature. Int J Radiat Oncol Biol Phys. 1993; 26 (3): 491-497.

25. Pelo S, Saponaro G, Patini R, Staderini E, Giordano A, Gasparini G, Garagiola U, Azzuni C, Cordaro M, Foresta E, Moro A: Risks in surgery-first orthognathic approach: complications of segmental osteotomies of the jaws. A systematic review. Eur Rev Med Pharmacol Sci. 2017; 21 (1): 4-12. Review

26. Velich N, Kádár B, Kiss G, Kovács K, Rétı F, Szigetı K, Garagiola $U$, SzABÓ G: Effect of human organism on the oxide layer formed on titanium osteosynthesis plates: a surface analytical study. J Craniofac Surg. 2006; 17 (6): 1144-1149.

27. Shives TC, Beabout JW, Unni KK: Massive osteolysis. Clin Orthop Relat Res. 1993; (294): 267-276.

28. Pelo S, Gasparini G, Garagiola U, Cordaro M, Di Nardo F, Staderini E, Patini R, de Angelis P, D'Amato G, Saponaro G, Moro A: Surgery-first orthognathic approach vs traditional orthognathic approach: Oral health-related quality of life assessed with 2 questionnaires. Am J Orthod Dentofacial Orthop. 2017; 152 (2): 250-254.

29. Naini FB, Cobourne MT, Garagiola U, McDonald F, Wertheim D: Nasofacial angle and nasal prominence: A quantitative investigation of idealized and normative values. J Craniomaxillofac Surg. 2016; 44 (4): 446-452.

30. Choma ND, Biscotti CV, Bauer TW, Mehta AC, Licata Aa: Gorham's syndrome: a case report and review of the literature. $A m$ J Med. 1987; 83 (6): 1151-1156.

31. Meller JL, Curet-Scott M, Dawson P, Besser AS, Shermeta DW: Massive osteolysis of the chest in children: an unusual cause of respiratory distress. J Pediatr Surg. 1993; 28 (12): 1539-1542.

32. TiE ML, Poland GA, Rosenow EC 3RD: Chylothorax in Gorham's syndrome: a common complication of a rare disease. Chest. 1994; 105 (1): 208-213.

33. Ruggieri P1, Montalti M, Angelini A, Alberghini M, Mercuri M: Gorham-Stout disease: the experience of the Rizzoli Institute and review of the literature. Skeletal Radiol. 2011; 40 (11): 1391-97.

34. Di Stefano DA, Garagiola U, Bassi MA: Preserving the Bone Profile in Anterior Maxilla using an Equine Cortical Bone Membrane and an Equine Enzyme-treated Bone Graft: A Case Report with 5-year Follow-up. J Contemp Dent Pract. 2017; 18 (7): 614621.

35. Salvatori P, Mincione A, Rizzi L, Costantini F, Bianchi A, Grecchi E, GARAGIOLA U, GRECCHI F: Maxillary resection for cancer, zygomatic implants insertion, and palatal repair as single-stage procedure: report of three cases. Maxillofac Plast Reconstr Surg. 2017; 25; 39 (1): 13.

36. Pelo S, Gasparini G, Garagiola U, Cordaro M, Di Nardo F, Staderini E, Patini R, de Angelis P, D'Amato G, Saponaro G, MoRO A: Surgery-first orthognathic approach vs traditional orthognathic approach: Oral health-related quality of life assessed with 2 questionnaires. Am J Orthod Dentofacial Orthop. 2017; 152 (2): 250-254.

37. Mignogna MD, Fedele S, Lo Russo L, Lanza A, Marenzi G, SamMARTINO G: Gorham's disease of the mandible mimicking periodontal disease on radiograph. J Clin Periodontol. 2005; 32 (9): 1022-1026. 
Alessandro Moro, Umberto Garagiola, Gianmarco Saponaro, Giulio Gasparini, Roberto Boniello, Marco Falchi, Giovanni Barbini, Enrico Cristallini, Giuseppe D’Amato, Bence Galambos, Sandro Pelo

\section{Gorha-Stout Disease of the upper jaw: case report and review of the literature}

Gorham's disease, or vanishing bone disease, is a rare condition of unknown etiology characterized by bone absorption. The disease can affect any part of the skeleton, however the pelvis, humerus, axial skeleton and the mandible are more frequently involved. The mechanism of bone resorption is unclear, but localized endothelial proliferation of lymphatic vessels is shown in osteolytic lesions The diagnosis is based on clinical, radiological and histological features after excluding other infectious, inflammatory, endocrine and neoplastic etiological factors. Medical treatment for Gorham's disease includes anti-osteoclastic medications (bisphosphonates), and alpha-2b interferon, radiation therapy induced sclerosis of the proliferating vascular tissue within the bone. Also surgical treatment options are available including resection of the lesion and reconstruction with bone grafts and/or prostheses. We present a case of Gorham's disease of the right maxilla in a 67 years old female affecting the alveolar process, zygoma and the floor of the orbit. The initial clinical manifestation at the onset of the disease was the mobility of the upper right molars, mimicking periodontal disease followed by the worsening of a preexisting diplopia with undefined origin. The patient received a medical treatment with zoledronic acid, vitamin $\mathrm{D}$ and calcium carbonate for 12 months which proved to be effective in controlling the progression of the disease.

Keywords: vanishing bone disease, bone resorbtions, endothelial proliferation, zoledronic acid therapy 